\title{
FAKTOR RISIKO KEJADIAN INFEKSI SALURAN PERNAFASAN AKUT PADA BALITA DI INDONESIA
}

\author{
Annisa Zolanda ${ }^{*}$; Mursid Raharjo $^{\mathrm{b}}$; Onny Setianic \\ a, b, c Jurusan Magister Kesehatan Lingkungan; Universitas Diponegoro \\ Jl. Prof. Sudarto No.13; Tembalang; Semarang; Jawa Tengah
}

\begin{abstract}
Abstrak
Infeksi Saluran Pernafasan Akut (ISPA) adalah penyakit yang disebabkan oleh virus atau bakteri yang biasanya menular sehingga dapat menimbulkan berbagai spektrum penyakit yang berkisar dari penyakit tanpa gejala sampai kepada penyakit yang parah dan mematikan, tergantung kepada patogen penyebabnya, faktor lingkungan, dan faktor pejamu. Tujuan penelitian ini adalah memberikan informasi mengenai faktor-faktor risiko kejadian ISPA pada balita berdasarkan kajian literatur review. Metode penelitian ini adalah literature review dengan menggunakan database sinta sebagai bahan acuan. Pengkategorian yang dilakukan oleh peneliti yaitu terindeks pada sinta 2-5, publikasi 10 tahun terakhir, dan mempunyai variabel yang berhubungan dengan faktor-faktor risiko kejadian ISPA pada balita. Hasil penelitian ini yaitu ditemukan bahwa terdapat faktor lingkungan yang dominan seperti: suhu, kelembaban, pencahayaan, ventilasi, dan kepadatan hunian merupakan faktor risiko yang menjadi penyebab kejadian ISPA pada balita. Kesimpulan dalam penelitian ini adalah terdapat faktor lingkungan, pendidikan ibu, kebiasaan merokok yang menjadi faktor risiko terhadap kejadian ISPA pada balita yang harus diperbaiki.
\end{abstract}

Kata kunci: ISPA, Bayi, Faktor Risiko

\begin{abstract}
[RISK FACTORS FOR THE INCIDENCE OF ACUTE RESPIRATORY INFECTION IN CHILDREN UNDER FIVE IN INDONESIA, Literature Review] Acute Respiratory Infection (ARI) is a disease caused by virus or bacteria that is usually contagious can cause a wide spectrum of diseases ranging from asymptomatic disease to severe and deadly disease, depending on the causative pathogen, environmental factors, and host factors. The purpose of this study was to provide information about the risk factors for the incidence of ARI in children under five based on literature review. This research method is a literature review using the Sinta database as a reference. Categorization was carried out by researchers, namely indexed in 2-5 sinta, publication of the last 10 years, and had variables related to risk factors for the incidence of ARI in children under five. The results of this study are found that there are dominant environmental factors such as: temperature, humidity, lighting, ventilation, and occupancy density are risk factors that cause the incidence of ARI in toddlers. The conclusion in this study is that there are environmental factors, maternal education, smoking habits which are risk factors for the incidence of ARI in toddlers that must be corrected.
\end{abstract}

Keywords: ARI, Baby, Risk Factors

\section{Pendahuluan}

Tujuan pembangunan berkelanjutan atau biasa dikenal dengan Suistanable Development Goals (SDGs) merupakan capaian target pembangunan yang berhubungan dengan pengembangan internasional yang disepakati

*) Correspondence Author (Annisa Zolanda)

E-mail: annzol1411@gmail.com lebih dari 190 negara menggantikan Millenium Development Goals (MDGs) pada akhir tahun 2015. SDGs berisi 17 tujuan yang disepakati dan berlaku bagi seluruh bangsa tanpa terkecuali. salah satunya dengan menjamin kehidupan yang sehat dan mendorong kesejahteraan bagi semua orang disegala usia. Untuk mencapai tujuan tersebut, terdapat 13 target yang harus dicapai. Beberapa target tersebut adalah pada tahun 2030 
mengakhiri epidemi AIDS, tuberkulosis, malaria, dan penyakit tropis yang terabaikan, serta memerangi hepatitis, penyakit bersumber air, dan penyakit menular lainnya. Kemudian, pada tahun 2030 secara substansial mengurangi angka kematian dan kesakitan oleh bahan kimia berbahaya dan udara, kontaminasi dan polusi air dan tanah.(Kementerian \& Ri, 2015)

Infeksi Saluran Pernafasan Akut (ISPA) merupakan penyakit yang sering terjadi pada masyarakat dan sudah dianggap biasa atau tidak membahayakan. ISPA merupakan penyakit saluran pernafasan atas atau bawah, disebabkan oleh virus atau bakteri yang biasanya menular sehingga dapat menimbulkan berbagai spektrum penyakit yang berkisar dari penyakit tanpa gejala sampai kepada penyakit yang parah dan mematikan, tergantung kepada patogen penyebabnya, faktor lingkungan, dan faktor pejamu. Sekelompok penyakit yang termasuk kedalam ISPA yaitu, Pneumonia, Influenza, dan Pernafasan Syncytial Virus (RSV).(Najmah, 2016)

ISPA masih menjadi penyebab utama morbiditas dan mortalitas penyakit menular di dunia. Angka mortalitas ISPA mencapai 4,25 juta setiap tahun di dunia. Berdasarkan data dari World Health Organization (WHO) tahun 2019 penyakit infeksi saluran pernapasan bawah menurunkan usia harapan hidup sebesar 2,09 tahun pada penderitanya.(WHO, 2019) Kelompok yang paling beresiko adalah balita. Sekitar $20-40 \%$ pasien dirumah sakit dikalangan anak-anak karena ISPA dengan sekitar 1,6 juta kematian karena pneumonia sendiri pada anak balita per tahun. Pada dewasa angka mortalitas pada dewasa (25-59 tahun) mencapai 1,65 juta.(Najmah, 2016)

Penyakit ISPA pada negara berkembang, merupakan $25 \%$ penyumbang kematian pada anak, terutama pada bayi usia kurang dari dua bulan. Indonesia termasuk kedalam salah satu negara berkembang dengan kasus ISPA tertinggi.(Dr.H.Masriadi, S.KM, S.Pd.I, S.Kg, M.Kes, 2017) ISPA di Indonesia selalu menempati urutan pertama penyebab kematian pada bayi dan balita. ISPA juga sering menempati daftar 10 penyakit terbanyak di rumah sakit dan puskesmas. ISPA masih menjadi masalah kesehatan di Indonesia karena dampak yang ditimbulkan sangatlah besar terhadap penderitanya, tidak hanya pada bayi dan balita, tetapi juga pada orang dewasa, selain itu ISPA juga dapat menjadi pemicu dari penyakit lainnya.(Najmah, 2016)

Riset Kesehatan Dasar (Riskesdas) Nasional
Tahun 2018 menunjukan prevalensi penyakit ISPA sebesar $(4,4 \%)$ dengan karakteristik penduduk yang mengalami ISPA tertinggi terdapat pada rentang usia 1-4 tahun $(25,8 \%)$. Adapun provinsi yang termasuk kedalam lima besar ISPA tertinggi adalah Papua, Bengkulu, Papua Barat, Nusa Tenggara Timur, dan Kalimantan Tengah.(RI, 2018)

Pada tahun 2017 berdasarkan data dari Laporan Rutin Subdit ISPA Tahun 2017, didapatkan insiden (per 1000 balita) di Indonesia sebesar 20,54\%.(Kemenkes RI, 2017) Pada tahun 2018 Berdasarkan data laporan ruin Subdit ISPA Tahun 2018, didapatkan insiden (per 1000 balita) di Indonesia sebesar 20,06\% hampir sama dengan data tahun sebelumnya 20,56\%.(Kemenkes RI, 2018) Sedangkan pada tahun 2019 angka kematian akibat pneumonia pada balita sebesar $0,12 \%$. Angka kematian akibat Pneumonia pada kelompok bayi lebih tinggi hampir dua kali lipat dibandingkan pada kelompok anak umur $1-4$ tahun.(Kemenkes RI, 2019)

ISPA merupakan penyakit yang tergolong ke dalam Air Borne Disease. Penularannya dapat terjadi melalui udara yang telah tercemar bibit penyakit dan masuk kedalam tubuh melalui saluran pernafasan. Penularan melalui udara terjadi tanpa kontak dengan penderita maupun dengan benda terkontaminasi. Namun, pada kenyataannya sebagian besar penularan melalui udara dapat juga menular melalui kontak langsung dengan penderita yang mengidap penyakit ISPA.(Najmah, 2016)

Secara umum terdapat tiga faktor risiko terjadinya ISPA, yaitu faktor lingkungan, faktor individu anak serta faktor perilaku. Faktor lingkungan meliputi: pencemaran udara dalam rumah, ventilasi rumah, dan kepadatan hunian. Faktor individu anak meliputi: umur anak (6-12 bulan/pada usia balita), berat badan lahir, status gizi, vitamin-A dan status imunisasi. Faktor perilaku meliputi perilaku pencegahan dan penanggulangan ISPA pada bayi atau peran aktif keluarga/masyarakat dalam menangani penyakit ISPA.(Depkes RI, 2004)

Rumah termasuk kedalam salah satu kebutuhan dasar bagi kehidupan manusia. Pertumbuhan penduduk yang tidak diikuti dengan pertambahan luas tanah cenderung menimbulkan masalah kepadatan populasi dan lingkungan tempat tinggal yang menyebabkan berbagai penyakit serta masalah kesehatan. Rumah juga merupakan salah satu bangunan tempat tinggal yang harus memenuhi kriteria kenyamanan, keamanan dan kesehatan guna 
mendukung penghuninya agar dapat bekerja dengan produktif.(Daryanto, 2015)

Konstruksi rumah dan lingkungan yang tidak memenuhi syarat kesehatan merupakan faktor risiko sumber penularan berbagai jenis penyakit. Penyakit infeksi saluran pernapasan akut (ISPA) erat kaitannya dengan kondisi perumahan. Sanitasi rumah dan lingkungan erat kaitannya dengan angka kejadian penyakit menular, terutama ISPA.(Ema, 2015) Bahkan pada kelompok bayi dan Balita, penyakit-penyakit berbasis lingkungan menyumbang lebih dari $80 \%$ dari penyakit yang diderita oleh bayi dan Balita. Keadaan tersebut mengindikasikan masih rendahnya cakupan dan kualitas intervensi kesehatan lingkungan.(Daryanto, 2015)

Pencemaran lingkungan seperti asap yang berasal dari sarana transportasi dan polusi udara dalam rumah merupakan ancaman kesehatan terutama ISPA. Perubahan iklim terutama suhu, kelembaban dan curah hujan merupakan beban ganda dalam pemberantasan penyakit ISPA, oleh karena itu upaya untuk tercapainya tujuan pemberantasan penyakit ISPA ialah dengan memperhatikan atau menanggulangi faktor risiko lingkungan.(Depkes RI, 2004)

\section{Metode}

Metode yang digunakan pada penelitian ini adalah scoping review dengan memusatkan kajian spesifik dari berbagai cakupan yang ditemukan untuk digabung dan menarik kesimpulan yang ringkas.(Sucharew \& Macaluso, 2019) Penelitian ini menggunakan sampel jurnal penelitian yang berada pada database sinta dari Kementerian Riset dan Teknologi, dengan kriteria :

1. Terindeks pada sinta $2-5$

2. Publikasi dalam 10 tahun terakhir (2015-2020)

3. Mempunyai variabel yang berhubungan dengan faktor risiko kejadian ISPA pada balita

\section{Hasil dan Pembahasan}

Tabel 1. Karakteristik Dan Variabel Jurnal

\begin{tabular}{|c|c|c|c|c|}
\hline Penulis & Metode & Sampel & Variabel & Hasil \\
\hline $\begin{array}{l}\text { Gita Nurina } \\
\text { Ramadhaniyanti, } \\
\text { Budiyono, } \\
\text { Nurjazuli.(Nurja } \\
\text { zuli \& Budiyono, } \\
\text { 2015) }\end{array}$ & $\begin{array}{l}\text { Jenis penelitian } \\
\text { adalah } \\
\text { Explanatory } \\
\text { Research yang } \\
\text { didalamnya } \\
\text { menjelaskan } \\
\text { hubungan kausal } \\
\text { antar variabel } \\
\text { penelitian. }\end{array}$ & $\begin{array}{l}\text { Jumlah sampel } \\
\text { yang dipakai } \\
\text { yaitu sebanyak } \\
64 \quad \text { sampel. } \\
\text { Teknik } \\
\text { pengambilan } \\
\text { sampel yang } \\
\text { digunakan } \\
\text { dalam penelitian } \\
\text { ini adalah } \\
\text { Systematic } \\
\text { Random } \\
\text { Sampling }\end{array}$ & $\begin{array}{l}\text { Kepadatan hunian } \\
\text { kamar tidur balita, } \\
\text { luas ventilasi } \\
\text { rumah, } \\
\text { kelembaban udara } \\
\text { kamar tidur balita, } \\
\text { kebiasaan anggota } \\
\text { keluarga merokok } \\
\text { di dalam rumah, } \\
\text { kebiasaan } \\
\text { menggunakan } \\
\text { obat nyamuk } \\
\text { bakar, dan } \\
\text { kebiasaan kaberadaan balita } \\
\text { di dapur saat } \\
\text { sedang memasak. }\end{array}$ & 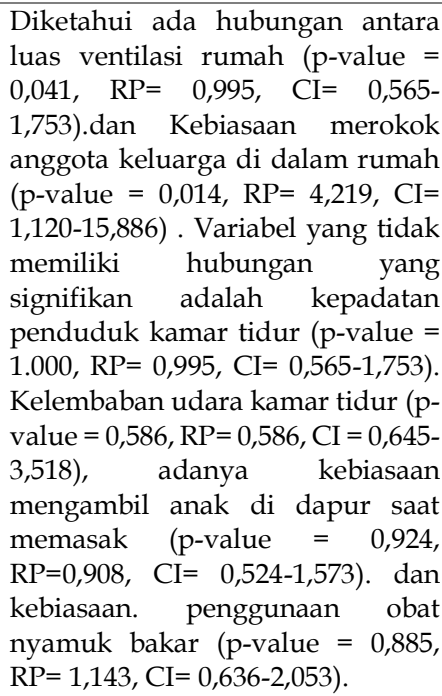 \\
\hline $\begin{array}{l}\text { Fauziah El Syani, } \\
\text { Budiyono, } \\
\text { Mursid } \\
\text { Raharjo.(Syani \& } \\
\text { Raharjo, 2016) }\end{array}$ & $\begin{array}{l}\text { Jenis penelitian ini } \\
\text { adalah } \\
\text { observasional } \\
\text { dengan desain } \\
\text { cross sectional. }\end{array}$ & $\begin{array}{lr}\text { Jumlah } & \text { sampel } \\
\text { sebanyak } & 98 \\
\text { responden } & \text { ibu } \\
\text { balitar yang } \\
\text { dihitung } & \text { dengan } \\
\text { rumus } & \text { besar } \\
\text { sampel } & \text { untuk } \\
\text { data } & \text { proporsi } \\
\text { sesuai } & \text { dengan } \\
\text { studi r cross } \\
\text { sectional dimana } \\
\text { teknik r } \\
\text { pengamnilan }\end{array}$ & $\begin{array}{l}\text { Jenis bahan bakar, } \\
\text { suhu, } \\
\text { kelembaban, } \\
\text { kepadatan } \\
\text { hunian, } \\
\text { kepadatan } \\
\text { penduduk, } \\
\text { kepadatan rumah, } \\
\text { tingkat ibu, } \\
\text { pendidikan ibkat } \\
\text { dan tingkapatan. }\end{array}$ & $\begin{array}{l}\text { Statistik Analisis menunjukkan } \\
\text { bahwa ada hubungan antara } \\
\text { kelembaban }(\mathrm{p}<0,001, \mathrm{RP}=7,59 \\
\text { dan CI 95\% }(2,867-20,135), \\
\text { kepadatan hunian }(\mathrm{p}=0,005, \mathrm{RP}= \\
3,203 \text { dan CI } 95 \%(1,399-7,333)) \text {, } \\
\text { kepadatan penduduk }(\mathrm{p}=0,038, \\
\mathrm{RP}=15 \text { dan CI } 95 \%(1,225- \\
183,630) \text {, dan tingkat pendapatan } \\
(\mathrm{p}=0,003, \mathrm{RP}=3,636 \text { dan CI } 95 \% \\
(1,529-8,649) \text { dengan kejadian } \\
\text { pneumonia pada balita. }\end{array}$ \\
\hline
\end{tabular}




\begin{tabular}{|c|c|c|c|c|}
\hline Penulis & Metode & Sampel & Variabel & Hasil \\
\hline $\begin{array}{l}\text { Fenti Dewi } \\
\text { Pertiwi.(Pertiwi } \\
\text { \& Farihah, 2017) }\end{array}$ & $\begin{array}{l}\text { Penelitian ini } \\
\text { menggunakan } \\
\text { metode kuantitatif } \\
\text { dengan rancangan } \\
\text { studi cross } \\
\text { sectional }\end{array}$ & $\begin{array}{l}\text { sampel dengan } \\
\text { proporsional } \\
\text { random } \\
\text { sampling. } \\
\text { Dari } \quad 3.130 \\
\text { populasi didapat } \\
45 \quad \text { sampel } \\
\text { penelitian. }\end{array}$ & $\begin{array}{l}\text { Faktor lingkungan } \\
\text { yang diteliti } \\
\text { dalam penelitian } \\
\text { ini meliputi: } \\
\text { kepadatan } \\
\text { hunian, yang } \\
\text { dibagi menjadi } \\
\text { kepadatan hunian } \\
\text { kamar tidur dan } \\
\text { kepadatan hunian } \\
\text { rumah, jenis } \\
\text { lantai, ventilasi, } \\
\text { pencahayaan, } \\
\text { kelembaban, suhu } \\
\text { dan jenis dinding } \\
\text { yang masing- } \\
\text { masing tergolong } \\
\text { atas ruang } \\
\text { keluarga dan } \\
\text { kamartinr ding }\end{array}$ & $\begin{array}{l}\text { Hasil penelitian menunjukkan } \\
\text { bahwa terdapat hubungan antara } \\
\text { faktor lingkungan: yaitu } \\
\text { pencahayaan kamar tidur }(\mathrm{p}= \\
0,148, \mathrm{OR}=3,016, \mathrm{CI} 85 \%=0,864) \text {, } \\
\text { kelembaban kamar tidur }(\mathrm{p}=0,142 \text {, } \\
\mathrm{OR}=2,597, \mathrm{CI} 85 \%=0,769) \text {, dan suhu } \\
\text { kamar tidur }(\mathrm{p}=0,148, \mathrm{OR}=3,016 \text {, } \\
\text { CI } 85 \%=0864) \text { dengan terjadinya } \\
\text { ISPA pada balita. }\end{array}$ \\
\hline $\begin{array}{l}\text { Wiwik } \\
\text { Setyaningsih, } \\
\text { Dodiet Aditya } \\
\text { Setyawan, Ari } \\
\text { Sarwanto.(Wiwik } \\
\text { Setyaningsih, } \\
\text { Dodiet Aditya } \\
\text { Setyawan, 2016) }\end{array}$ & $\begin{array}{l}\text { Desain penelitian } \\
\text { adalah Analitik } \\
\text { Observasional } \\
\text { dengan } \\
\text { pendekatan Case } \\
\text { Control } \\
\text { menggunakan } \\
\text { pemodelan Sistem } \\
\text { Informasi } \\
\text { Geografis (SIG). }\end{array}$ & $\begin{array}{l}\text { Sampel diambil } \\
\text { secara Purposive } \\
\text { dengan jumlah } \\
80 \text { responden. }\end{array}$ & $\begin{array}{l}\text { Jenis kelamin, } \\
\text { Kepadatan } \\
\text { penghuni rumah, } \\
\text { Paparan asap } \\
\text { rokok, Jarak } \\
\text { rumah dengan } \\
\text { jalan raya }\end{array}$ & $\begin{array}{l}\text { Hasil penelitian tersebut dapat } \\
\text { disimpulkan bahwa faktor-faktor } \\
\text { risiko yang terbukti secara } \\
\text { signifikan berhubungan dengan } \\
\text { kejadian penyakit ISPA pada anak } \\
\text { di kecamatan Sragen adalah } \\
\text { Kepadatan Penghuni Rumah (OR } \\
=0.075,95 \% \mathrm{CI}=0.019-0.293 \text {, } \\
\text { dengan nilai } \mathrm{p}=0.000) \text {; dan Jarak } \\
\text { Tempat Tinggal yang Dekat } \\
\text { dengan Jalan Raya yaitu dalam } \\
\text { Radius } \leq 250 \text { Meter }(\mathrm{OR}=0.334 \text {, } \\
95 \% \mathrm{CI}=0.118-0.949 \text {, dengan nilai } \\
\mathrm{p}=0.040) \text {. Sedangkan faktor risiko } \\
\text { yang terbukti paling dominan } \\
\text { berhubungan kejadian penyakit } \\
\text { ISPA pada anak di kecamatan } \\
\text { Sragen adalah jarak tempat tinggal } \\
\text { dengan jalan raya dalam radius } \leq \\
250 \text { meter dengan OR }=0.334,95 \% \\
\mathrm{CI}=0.118-0.949 \text {, dengan nilai } \mathrm{p}= \\
0.040 .\end{array}$ \\
\hline $\begin{array}{l}\text { Irma Rahayu, } \\
\text { Nani Yuniar, } \\
\text { Andi Faizal } \\
\text { Fachlevy.(Irma } \\
\text { Rahayu., Nani } \\
\text { yuniar., 2017) }\end{array}$ & $\begin{array}{l}\text { Jenis penelitian } \\
\text { bersifat } \\
\text { observasional } \\
\text { analitik dengan } \\
\text { pendekatan cross } \\
\text { sectional study }\end{array}$ & $\begin{array}{l}\text { Sampel sebanyak } \\
84 \quad \text { responden } \\
\text { dengan } \\
\text { menggunakan } \\
\text { teknik simple } \\
\text { random } \\
\text { sampling. }\end{array}$ & $\begin{array}{lr}\begin{array}{l}\text { Kepadatan } \\
\text { hunian, }\end{array} & \text { Luas } \\
\text { ventilasi, } & \text { Jenis } \\
\text { dinding, Langit- } & \\
\text { langit rumah, } & \text { rumaran asap } \\
\text { Paparan } & \text { rokok, Pemberian } \\
\text { ASI r ekslusif, } & \text { Status imunisasi }\end{array}$ & $\begin{array}{l}\text { Hasil Penelitian menunjukkan } \\
\text { bahwa ada hubungan antara } \\
\text { kepadatan hunian }(\mathrm{p} \text { value }= \\
0,007,) \text {, Luas Ventilasi ( } \mathrm{p} \text { value }= \\
0,013<\mathrm{\alpha}) \text {, jenis dinding }(\mathrm{p} \text { value }= \\
0,015<\mathrm{a}), \text { langit-langit rumah }(\mathrm{p} \\
\text { value }=0,005<\mathrm{\alpha}), \text { paparan asap } \\
\text { rokok }(\mathrm{p} \text { value }=0,019<\mathrm{\alpha}), \\
\text { pemberian ASI Ekslusif }(\mathrm{p} \text { value }= \\
0,005<\mathrm{a}) \text { dan status imunisasi }(\mathrm{p} \\
\text { value }=0,019<\mathrm{a}) \text { dengan kejadian } \\
\text { ISPA pada balita di Puskesmas } \\
\text { Soropia Kabupaten Konawe tahun } \\
\text { 2017. }\end{array}$ \\
\hline $\begin{array}{l}\text { Adhasari } \\
\text { Agungnisa.(Agu } \\
\text { ngnisa, 2019) }\end{array}$ & $\begin{array}{l}\text { Penelitian ini } \\
\text { merupakan } \\
\text { penelitian } \\
\text { observasional, } \\
\text { dengan desain } \\
\text { cross sectional. }\end{array}$ & $\begin{array}{l}\text { Sampel } \\
\text { penelitian } \\
\text { sebesar } 60 \text { balita, } \\
\text { diambil secara } \\
\text { simple random } \\
\text { sampling }\end{array}$ & $\begin{array}{lr}\text { Kepadatan hunian } \\
\text { kamar, Luas } \\
\text { ventilasi, Suhu } \\
\text { udara, } \\
\text { Kelembapan, } \\
\text { Pencahayaan }\end{array}$ & $\begin{array}{l}\text { Hasil penelitian menunjukkan } \\
\text { kepadatan hunian kamar balita } \\
(\mathrm{p}=0,004) \text { berpengaruh terhadap } \\
\text { kejadian ISPA pada balita, } \\
\text { sedangkan luas ventilasi }(\mathrm{p}=0,239) \text {, } \\
\text { suhu udara }(\mathrm{p}=0,750), \text { kelembapan } \\
(\mathrm{p}=0,720), \text { dan pencahayaan } \\
(\mathrm{p}=0,612) \text { tidak berpengaruh }\end{array}$ \\
\hline
\end{tabular}




\begin{tabular}{|c|c|}
\hline Penulis & Metode \\
\hline $\begin{array}{l}\text { Suci Wulandhani, } \\
\text { A. Bida } \\
\text { Purnamasari. } \\
\text { (Wulandhani \& } \\
\text { Purnamasari, } \\
\text { 2019) }\end{array}$ & $\begin{array}{l}\text { Metode analisis } \\
\text { data yang } \\
\text { digunakan adalah } \\
\text { dengan menduga } \\
\text { parameter dari } \\
\text { data mengenai } \\
\text { penyakit ISPA uji } \\
\text { statistik cross tab } \\
\text { dengan tingkat } \\
\text { kepercayaan 95\%, } \\
\text { a }=5 \%\end{array}$ \\
\hline
\end{tabular}

Aulia Noviyanti Noor, Hansen. (Noor, 2020)

Rahmi Garmini, Rachmadhi Purwana.(Garmi ni \& Purwana, 2020)

\section{Penelitian} adalah penelitian kuantitatif dengan desain Case Control. Analisis data dalam penelitian in menggunakan Koefisien Kontingensi C

Jenis penelitian analitik, desain penelitian cross sectional.

ini enis sebanyak responden (Kelompok Kasus) responden (Kelompok dari pengambilan sampel dalam penelitian in menggunakan Teknik Accidental Sampling Populasi penelitian adalah anak balita berumur 12-59 bertempat tinggal Kelurahan Sukajaya dan sampel berjumlah 94 orang. Kontrol). Teknik bulan yang
Variabel terukur adalah kondisi udara dalam rumah, karakteristik balita, dan di kejadian ISPA pada balita. fisik : Kepadatan

hunian, Ventilasi,

Jenis lantai,

Dinding rumah Jarak rumah, membersihkan rumah

Hasil

terhadap kejadian ISPA pada balita.

Hasil penelitian menunjukkan bahwa ada hubungan yang bermakna antara kepadatan hunian $(\mathrm{OR}=2.030, \mathrm{RR}=0.635,95 \%$ CI : $0.673-6.128)$, ventilasi $(\mathrm{OR}=0.814 ， \mathrm{RR}=1.138,95 \% \mathrm{CI}$ : $0.280-2.369)$, jenis lantai $(\mathrm{OR}=0.768$, $\mathrm{RR}=1.173$, 95\% CI : 0.155-3.802), jenis dinding $(\mathrm{OR}=5.294, \mathrm{RR}=0.324$, 95\% CI :1.499-18.695) jarak antara rumah dengan jalan raya (OR=1.167, RR=0.909, 95\% CI : 0.351-3.881) dan kebiasaan membersihkan debu dalam rumah $(\mathrm{OR}=1.228, \quad \mathrm{RR}=0.879,95 \% \mathrm{CI}$ : 0.422-3.572) dengan kejadian ISPA.

Pada variable kepadatan hunian kamar didapatkan nilai $P$ Value= 0.11 yang dapat dinyatakan bahwa ada hubungan antara kepadatan hunian kamar dengan kejadian ISPA pada balita, serta dengan nilai $\mathrm{OR}=0.016$.

Pada analisis yang telah dilakukan di variable suhu dengan uji Koefisien Kontingensi C didapatkan hasil bahwa tidak terdapat atau tidak ada hubungan antara variable suhu dengan kejadian ISPA pada balita, dengan nilai $P$ Value $=0.11$ dan $O R=0.273$.

Period Prevalence kejadian ISPA pada balita sebesar $59,6 \%$. Variabel penggunaan obat anti nyamuk ( $\mathrm{p}$ value $=0,021 \quad \mathrm{OR}=0,034, \quad \mathrm{C}$ $95 \%=1,226-7,316)$, perokok dalam rumah ( $\mathrm{p}$ value $=0,047 \mathrm{OR}=2,556$, CI $95 \%=1,097-5,956)$, ventilasi ( $p$ value $=0,002 \quad \mathrm{OR}=4,650, \quad \mathrm{CI}$ $95 \%=1,814-11,918)$, status gizi ( $p$ value $=0,008 \quad \mathrm{OR}=3,522, \quad \mathrm{CI}$ $95 \%=1,460-8,493)$ dan status imunisasi ( $p$ value $=0,032$ $\mathrm{OR}=2,832$, CI $95 \%=1,179-6,801$ ) secara statistik menunjukkan hubungan yang bermakna terhadap kejadian ISPA pada balita, sedangkan variabel kadar $\mathrm{SO} 2$ dalam rumah ( $\mathrm{p}$ value $=0,138$ $\mathrm{OR}=0,285$, CI $95 \%=0,054-1,495)$ dan umur balita ( $\mathrm{p}$ value $=0,904$ $\mathrm{OR}=0,869$, CI $\quad 95 \%=0,380-1,988)$ secara statistik tidak menunjukkan hubungan yang bermakna terhadap kejadian ISPA pada balita. Hasil analisis multivariat diperoleh bahwa variabel ventilasi rumah merupakan variabel yang paling dominan berhubungan dengan kejadian ISPA pada balita.

Sampel sebanyak PM10, Suhu, Hasil penelitian menunjukan 184 siswa kelas 4 kelembaban, bahwa variabel yang berhubungan dan 5 sekolah pencahayaan, dengan kejadian ISPA pada siswa dasar yang ventilasi dan SD/MI yaitu PM10 berada di tiga kepadatan hunian $(\mathrm{p}=0,0001 ; \mathrm{OR}=3,862)$, pencahayaan 


\begin{tabular}{|c|c|c|c|c|}
\hline Penulis & Metode & Sampel & Variabel & Hasil \\
\hline & & sekolah terpilih. & $\begin{array}{l}\text { ruang kelas, serta } \\
\text { status gizi siswa. }\end{array}$ & $\begin{array}{lr}\text { ( } \mathrm{p}=0,006 ; \mathrm{OR}=3,111), & \text { dan } \\
\text { kepadatan hunian } & \text { kelas } \\
(\mathrm{p}=0,002 ; \mathrm{OR}=2,952) . & \text { Setelah } \\
\text { dikontrol dengan variabel } & \text { vonfonding, didapatkan bahwa } \\
\text { siswa yang berada dalam ruang } \\
\text { kelas dengan konsentrasi PM10 di } \\
\text { atas median dan kepadatan hunian } \\
\text { yang tidak memenuhi syarat } \\
\text { berisiko 4,5 kali untuk mengalami } \\
\text { kejadian ISPA dibandingkan } \\
\text { dengan siswa yang berada di } \\
\text { ruang kelas dengan konsentrasi di } \\
\text { bawah median dan kepadatan } \\
\text { hunian yang memenuhi syarat. }\end{array}$ \\
\hline
\end{tabular}

Suhu

Permenkes RI 1077/2011 tentang Pedoman Penyehatan Udara dalam Ruang Rumah menyebutkan bahwa suhu yang diperkenankan di dalam sebuah rumah adalah $18^{\circ} \mathrm{C}-30^{\circ} \mathrm{C}$. Suhu udara merupakan salah satu indikator yang menentukan kualitas udara di dalam rumah, kualitas udara yang kurang baik dapat memicu timbulnya berbagai macam penyakit yang berhubungan dengan pernapasan, seperti ISPA.(Menteri Kesehatan RI, 2011)

Berdasarkan penelitian yang telah dilakukan oleh Gita Nurina Ramadhaniyanti, Budiyono, Nurjazuli (2015) menunjukkan bahwa terdapat ada hubungan antara luas ventilasi rumah ( $\mathrm{p}$ value $=0,041$ ) dengan kejadian ISPA pada balita.(Menteri Kesehatan RI, 2011)

\section{Kelembaban}

Kelembaban sangat erat hubungannya dengan ventilasi. Apabila ventilasi kurang baik maka akan mengakibatkan meningkatnya kelembaban yang disebabkan oleh penguapan cairan tubuh dan uap pernapasan. Rumah yang tidak memiliki kelembaban udara yang memenuhi syarat kesehatan (40 \% -70 \%) akan membawa pengaruh terhadap penghuninya. Rumah yang lembab merupakan media yang baik bagi pertumbuhan mikroorganisme antara lain bakteri, spiroket, ricketsia dan virus. Mikroorganisme tersebut dapat masuk kedalam tubuh melalui udara sehingga dapat menyebabkan penyakit infeksi, khususnya penyakit infeksi saluran pernapasan (ISPA).

Berdasarkan penelitian yang telah dilakukan oleh Fenti Dewi Pertiwi (2017) terdapat hubungan antara kelembaban kamar tidur $(\mathrm{p}=0,142)$ terhadap kejadian ISPA pada balita.

\section{Pencahayaan}

PERMENKES No. 1077/ MENKES/ PER/ V/ 2011 tentang pedoman penyehatan udara di dalam ruang rumah persyaratan pencahayaan di dalam rumah minimal 60 lux. Rumah yang sehat memerlukan cahaya yang cukup, tidak kurang dan tidak terlalu banyak. Kurangnya cahaya yang masuk ke dalam rumah menyebabkan kurang nyaman, dan juga dapat menjadi media atau tempat yang baik untuk hidup dan berkembangnya bibit penyakit.(Menteri Kesehatan RI, 2011)

Berdasarkan penelitian yang telah dilakukan oleh Agisna Nur Fidya, Budi Hartono (2020), didapatkan hasil bahwa terdapat hubungan antara pencahayaan $(p=0,006 ; O R=3,111)$ dengan kejadian ISPA pada balita.

\section{Ventilasi}

Kepmenkes No. 829/Menkes/SK/VII/1999 tentang persyaratan rumah tinggal luas penghawaan atau ventilasi alami yang permanen minimal $10 \%$ dari luas lantai.(Kementerian Kesehatan RI, 1999) Ventilasi alami rumah berfungsi sebagai tempat terjadinya sirkulasi pergantian udara dari dalam rumah ke luar rumah yang cukup, sehingga akan menjaga keseimbangan kadar oksigen yang diperlukan oleh penghuni rumah. Sehingga udara didalam rumah selalu terjaga kesegaran dan kebersihannya.(Notoatmodjo S, 2014)

Berdasarkan penelitian yang telah dilakukan oleh Suci Wulandhani (2019), A. Bida Purnamasari menunjukkan bahwa ada hubungan yang bermakna antara ventilasi $(\mathrm{OR}=0.814$, $\mathrm{RR}=1.138$, 95\% CI: 0.280-2.369), terhadap kejadian ISPA pada balita.

Kepadatan Hunian

Berdasarkan Kepmenkes No. 829/ Menkes/ SK/ VII/ 1999 tentang persyaratan 
rumah tinggal dimana luas kamar tidur minimal $8 \mathrm{~m}^{2}$ dan tidak dianjurkan digunakan oleh lebih dari dua orang tidur dalam satu ruang tidur, kecuali anak dibawah umur 5 tahun. Hal ini akan menyebabkan kurangnya konsumsi $\mathrm{O}_{2}$ bagi penghuni kamar, dan apabila salah satu anggota keluarga terkena penyakit infeksi akan mudah menular kepada anggota keluarga yang lain.(Kementerian Kesehatan RI, 1999)

Berdasarkan penelitian yang telah dilakukan oleh Irma Rahayu, Nani Yuniar, Andi Faizal Fachlevy (2017), menunjukkan bahwa ada hubungan antara kepadatan hunian ( $\mathrm{p}$ value $=$ $0,007<a$ ) dengan kejadian penyakit ISPA pada balita.

\section{Simpulan dan Saran}

Hasil dalam penelitian ini didapatkan bahwa terdapat beberapa faktor risiko yang berhubungan dengan kejadian ISPA pada balita. Faktor lingkungan, pendidikan ibu, kebiasaan merokok juga mempengaruhi terjadinya ISPA pada balita. Faktor lingkungan yang dominan pada penelitian ini yaitu: suhu, kelembaban, pencahayaan, ventilasi, dan kepadatan hunian

Diharapkan agar faktor lingkungan harus memenuhi syarat-syarat kesehatan yang bertujuan untuk mencegah datangnya penyakit, khususnya ISPA pada balita.

\section{Ucapan Terima Kasih}

Peneliti mengucapkan terima kasih kepada keluarga yang selalu mendoakan dan mendukung saya sehingga artikel literature review ini terselesaikan dengan baik. Peneliti juga mengucapkan terima kasih kepada dosen pembimbing yang selalu gigih membimbing dalam kemajuan dari artikel ini.

\section{Daftar Pustaka}

Agungnisa, A. (2019). Physical Sanitation of the House that Influence the Incidence of ARI in Children under Five in Kalianget Timur Village. Jurnal Kesehatan Lingkungan, 11(1), 1. https://doi.org/10.20473/jkl.v11i1.2019.1-9

Daryanto, M. (2015). Pengelolaan Kesehatan Lingkungan. Yogyakarta: Gava Medika.

Depkes RI. (2004). Pedoman Pemberantasan Penyakit ISPA Untuk Penanggulangan Pneumonia Pada Balita.

Masriadi. . (2017). Epidemiologi Penyakit Menular (II). Depok: PT. RAJAGRAFINDO
PERSADA.

Ema, M. (2015). Analisis Faktor Risiko Kejadian ISPA di tinjau dari status rumah di wilayah kerja Puskesas Kota wilayah Utara Kota Kediri.

Garmini, R., \& Purwana, R. (2020). Polusi Udara Dalam Rumah Terhadap Infeksi Saluran Pernafasan Akut pada Balita di TPA Sukawinatan Palembang. Jurnal Kesehatan Lingkungan Indonesia, 19(1), 1. https://doi.org/10.14710/jkli.19.1.1-6

Irma Rahayu., Nani yuniar., A. F. F. (2017). Faktor yang Berhubungan dengan Kejadian Penyakit ISPA Pada Balita di Wilayah Kerja Puskesmas Soropia Kabupaten Konawe tahun 2017. Jurnal Ilmiah Mahasiswa Kesehatan, 3(3), 1-12.

Kementerian Kesehatan RI. (2017). Profil Kesehatan Indonesia 2017 (Vol. 1227). https://doi.org/10.1002/qj

Kementerian Kesehatan RI. (2018). Profil Kesehatan Indonesia 2018 [Indonesia Health Profile 2018]. Retrieved from http://www.depkes.go.id/resources/dow nload/pusdatin/profil-kesehatanindonesia/Data-dan-Informasi_ProfilKesehatan-Indonesia-2018.pdf

Kementerian Kesehatan RI. (2019). Profil Kesehatan Indonesia Tahun 2019. Kementrian Kesehatan Repoblik Indonesia (Vol. 42).

Kementerian Kesehatan RI. (1999). Syarat Kesehatan Perumahan

Kementerian Kesehatan RI. (2015). Kesehatan Dalam Kerangka Sustainable Development Goals (SDGs), (97).

Menteri Kesehatan RI. (2011). Permenkes No. 1077/MENKES/PER/V/2011 tentang Pedoman Penyehatan Udara Dalam Ruang Rumah

Najmah. (2016). Epidemiologi Penyakit Menular. (T. Ismail, Ed.) (1st ed.). Jakarta: CV.Trans Info Media.

Noor, A. N. (2020). Hubungan Lingkungan Fisik dan Status Gizi dengan Kejadian ISPA Pada Balita di Wilayah Kerja Puskesmas Sidomulyo Kota Samarinda. Borneo Student Research, 1(3), 146-151.

Notoatmodjo S. (2014). Kesehatan Masyarakat: Ilmu Dan Seni. Jakarta: Rineka Cipta. 
Nur Fidya, A., \& Hartono, B. (2020). PM10 Dalam Udara Ruang Kelas dengan Kejadian ISPA Pada Siswa SD/MI di Wilayah Kerja Puskesmas Cilebut, Kecamatan Sukaraja, Kabupaten Bogor, 1(2), 65-74.

Nurjazuli, Ramadhaniyanti G. N., \& Budiyono. (2015). Perilaku Yang Berhubungan Dengan Kejadian Infeksi Saluran Pernafasan Akut ( Ispa ) Pada Balita Di Kelurahan Kuningan. Jurnal Kesehatan Masyarakat (e-Journal), 3(1).

Pertiwi, F. D., \& Farihah, N. (2017). Hubungan Lingkungan Dengan Kejadian Infeksi Saluran Pernafasan Akut (Ispa) Pada Balita Di Wilayah Kerja Uptd Puskesmas Semplak Tahun 2016. Hearty, 5(2). https://doi.org/10.32832/hearty.v5i2.1056

Kementerian Kesehatan RI. (2018). Hasil Utama Riskesdas 2018.

Sucharew, H., \& Macaluso, M. (2019). Methods for research evidence synthesis: The scoping review approach. Journal of Hospital Medicine, 14(7), 416-418. https://doi.org/10.12788/jhm.3248

Syani, F. El, \& Raharjo, M. (2016). Hubungan
Faktor Risiko Lingkungan Terhadap Kejadian Penyakit Pneumonia Balita Dengan Pendekatan Analisis Spasial Di Kecamatan Semarang Utara. Jurnal Kesehatan Masyarakat (e-Journal), 3(3), 732744 .

WHO. (2019). Monitoring Health For The SDGs. Swiss.

Wiwik Setyaningsih, Dodiet Aditya Setyawan, A. S. (2016). Studi Epidemiologi Dengan Pendekatan Analisis Spasial Terhadap Faktor-Faktor Risiko Penyakit Infeksi Saluran Pernapasan Akut (Ispa) Pada Anak Di Kecamatan Sragen, 01, 44-50. Retrieved from http://jurnal.poltekkessolo.ac.id/index.php/JKG/article/downlo ad/355/317

Wulandhani, S., \& Purnamasari, A. B. (2019). Analisis Faktor Risiko Kejadian Infeksi Saluran Pernapasan Akut ditinjau dari Lingkungan Fisik. Sainsmat: Jurnal Ilmiah Ilmu Pengetahuan Alam, 8(2), 70. https://doi.org/10.35580/sainsmat8210721 2019 